\title{
How Exercise and Dietary Intervention Affect the Outcome of Osteosarcopenic Obesity Syndrome?
}

\author{
Pegah JafariNasabian
}

Department of Nutrition, Food and Exercise Sciences, Florida State University, Tallahassee, FL 32306, USA; pjafarinasabian@fsu.edu; Tel.: +1-850-296-6636

Received: 30 April 2018; Accepted: 25 May 2018; Published: 28 May 2018

\begin{abstract}
Osteosarcopenic obesity (OSO) is described as the simultaneous presence of osteopenia/osteoporosis, sarcopenia, and increased adiposity. Over time, older adults with OSO syndrome might be at greater risk for loss of physical function and bone fractures. Furthermore, a sedentary lifestyle, inadequate nutrition, pharmaceutical drugs, and chronic conditions encompass the multifactorial nature of OSO syndrome. Physical activity and a healthy diet play a crucial role in management and treatment of OSO syndrome. Research has shown that even low-intensity physical activity or daily habitual activity can maintain bone mineral density, muscle strength, and improve muscle quality, and reduce adiposity. However, older adults with high risk of fall and injuries require tailored exercise intensity. Also, balanced daily intake of vitamin $\mathrm{D}$, calcium, and protein is important in prevention and treatment of OSO syndrome in postmenopausal women. Effective measurement of bone mass, muscle mass, and strength is required when detecting OSO syndrome and to evaluate the balance, strength and endurance of elder individuals and severity of the condition.
\end{abstract}

Keywords: osteosarcopenic obesity; exercise; diet; aging; fall

\section{Introduction}

Osteosarcopenic obesity (OSO) syndrome is accompanied by changes in body composition, including deterioration of bone mass (manifested as osteopenia/osteoporosis), decline in muscle strength and muscle mass (sarcopenia), and increased presence of adipose tissue or fat redistribution in the abdominal region and its infiltration into bone and muscle (Figure 1) [1,2]. Although OSO syndrome has been previously diagnosed among younger individuals [3], the older adults (specifically, postmenopausal women over the age of 65) and patients with chronic conditions have a particular higher risk for OSO syndrome [2,4,5]. Specifically, in older women, there is an age-related loss of bone, lean mass and muscle strength, and gain in adiposity [4]. It is important to take into consideration that young obese individuals with decreased lean body mass have a higher chance of developing OSO syndrome and frailty earlier than healthy lean individuals [3]. Refer to Table 1 for risk factors involved in etiology of OSO syndrome.

Given the severe consequences of OSO syndrome on general health status and quality of life in the elderly population, early prevention measures are required to evaluate its progression and halt its advancement. Therefore, the purpose of this document is to give an overview of the literature regarding the precise pathophysiologic processes, diagnostic criteria, and effective physical measurements to evaluate the severity of OSO syndrome. The current review will look into the management of OSO syndrome through diet and exercise, as well as its relationship with fall risk.

Aging is not only associated with increased adiposity, but also with fat redistribution and infiltration into the bone and muscle tissues [1,4]. Skeletal muscle, bone, and fat masses are all derived from shared mesenchymal stem cells [6]. When the body is affected by systemic low-grade inflammation, it will result in exacerbated adipogenesis and suppressed osteoblastogenesis and 
myogenesis in adults [7-10]. Visceral adiposity has a negative impact on bone and muscle health by promoting low-grade chronic inflammation [11,12]. Adipose tissue is involved in secreting pro-inflammatory cytokines, such as tumor necrosis factor-alpha, interleukin 1 and 6, and C-reactive protein $[7,13-16]$. Therefore, excess adiposity, which itself is associated with increased secretion of inflammatory mediators, may decrease osteogenesis and myogenesis $[7,9]$.

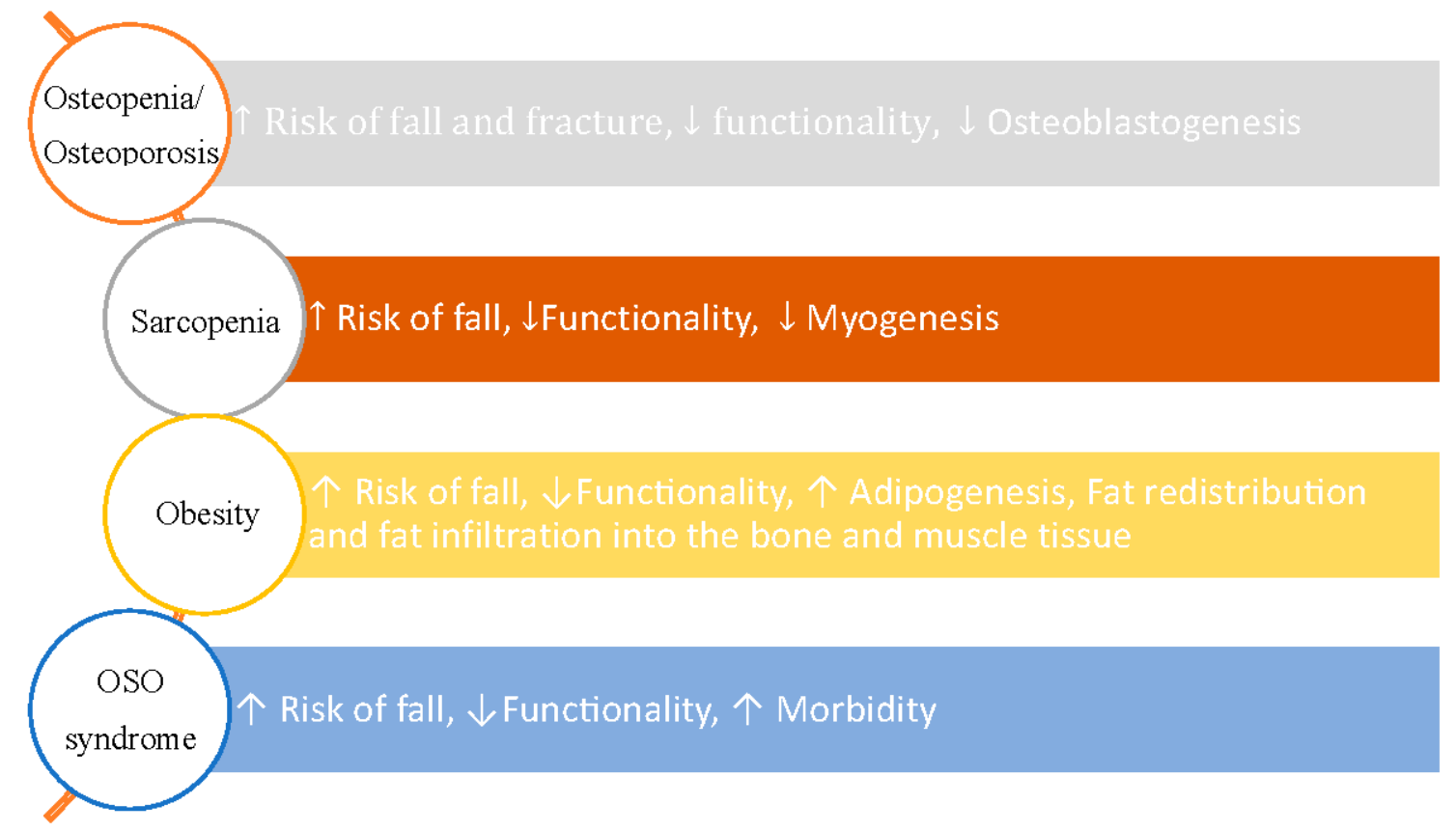

Figure 1. Osteosarcopenic obesity consequences. $\uparrow:$ increased; $\downarrow$ : decreased

Table 1. Factors associated with development of osteosarcopenic obesity syndrome.

\begin{tabular}{cc}
\hline Intrinsic Factors $[4,5,17,18]$ & Extrinsic Factors [2,18-21] \\
\hline Age & Medication \\
Gender & Diet \\
Chronic diseases & Exercise \\
Muscular strength & \\
Skeletal muscle mass & \\
Percentage of body fat & \\
Bone mineral density & \\
\hline
\end{tabular}

\section{Diagnostic Criteria}

The criteria for the diagnosis of OSO syndrome is based on the combination of diagnostic criteria reflecting bone, muscle, and fat impairment. Ilich et al., [2] used a combination of several criteria for diagnosing OSO syndrome, which include (a) $T$-scores $\leq-1.0$ standard deviation (SD) of the lumbar spine $\left(\mathrm{L}_{1}-\mathrm{L}_{4}\right)$ and / or femoral neck [22], (b) the 20th percentile of the residual distribution for appendicular lean mass (ALM) with cut-off point $\leq-1.43$ for diagnosing sarcopenia [23], and (c) body fat $\geq 32 \%$ dual-energy $X$-ray absorptiometry (DXA) [23]. The current diagnostic criteria are based on several recent studies [24-28]. Refer to Table 2 for detailed diagnostic criteria of OSO syndrome based on $T$-score and body composition. 
Table 2. Diagnostic criteria of OSO syndrome based on bone density and body composition.

\begin{tabular}{cccc}
\hline Condition & $\begin{array}{c}\text { T-Score } \leq-\mathbf{1 . 0} \text { SD at the Femoral } \\
\text { Neck, or Lumbar Spine }\end{array}$ & $\begin{array}{c}<\text { 20th Percentile of } \\
\text { ALM for Women }\end{array}$ & $\begin{array}{c}\text { Fat Mass } \geq \mathbf{3 2} \% \\
\text { for Women }\end{array}$ \\
\hline Osteopenia/osteoporosis & Yes & No & No \\
Sarcopenia & No & Yes & No \\
Obesity & No & No & Yes \\
OSO & Yes & Yes & Yes \\
\hline
\end{tabular}

ALM: appendicular lean mass; OSO: osteosarcopenic obesity; SD: standard deviation; ALM $=-17.4+18.3 \times$ height $(\mathrm{m})+0.16 \times$ body fat $(\mathrm{kg})$.

\section{Diet and Exercise in OSO Population}

The elderly population face a challenge in following a healthy diet, due to diminished appetite, changes in taste and smell, poor dentition, and chronic diseases [29]. Moreover, absorption of many nutrients decreases with aging [4,29]. Diet plays a vital role in maintaining bone health and body composition. A recent study showed women with OSO syndrome have a lower daily intake of vitamin D and calcium (diet and supplements) in comparison to those who were osteopenic obese, only osteopenic, sarcopenic, or obese [25], suggesting potential health benefits of maintaining an adequate intake of vitamin D and calcium. Moreover, low serum vitamin D concentrations have been observed in the population with OSO syndrome [30]. Insufficient protein intake can increase muscle wasting in aging adults [31,32]. Based on a recent recommendation for OSO population, high protein diet (1.4-1.6 g/ $\mathrm{kg} /$ day) is required to maintain muscle quality and muscle mass [18]. Also, a recent study on postmenopausal women showed a significant positive correlation between the total amount of protein intake, and right femoral neck bone mineral density and T-score [25]. However, it is important to balance high protein diets with calcium and vitamin D, as an extensive high protein diet is associated with increased urinary calcium excretion, which may affect bone mineral density $[33,34]$. Aside from energy imbalance and lower protein intakes, it has been revealed that high levels of simple carbohydrates and low omega-3 polyunsaturated fatty acids may also contribute to OSO syndrome $[18,20]$. It is also worth noting that the elderly, including frail women living in an assisted living facility or living alone, tend to rely on someone else for food preparation. This lifestyle may result in reduced protein and total energy intake [20,35]. Finally, several studies have shown that the nutrient composition of the Western diet may not promote healthy aging, and may contribute to the development of OSO syndrome [7,19,20,36,37].

Considerable evidence exists regarding the fact that low physical activity combined with inadequate nutrient intake may further aggravate the decline in muscle protein synthesis and contribute to muscle loss in older adults $[19,20,38]$. Resistance training may reduce fat mass [39] while improving bone mineral density $[40,41]$. A recent study by Cunha et al., showed that 12 week resistance training is effective in improving the risk factors of OSO syndrome among older women ( $\geq 60$ years old) [5]. In another study with a longer duration of intervention (12 month exercise program combining aerobic step, flexibility/postural control training, and resistance training) on postmenopausal Caucasian women revealed an increase in skeletal muscle mass [42]. It is clear that resistance and aerobic exercises require at least some level of functionality in the elderly population. However, aging is often associated with comorbidities, in addition to the physical changes to bone, and body composition $[4,17]$. There are many barriers to exercise for frail populations due to their physical limitations [43]. Therefore, conventional resistance and aerobic exercises may not be the best viable option for OSO population as the first line of treatment. Unconventional activities (tai chi, yoga, Pilates, etc.) might be more suitable for older population $[18,21]$. The results of several studies on the effects of tai chi in sedentary obese women suggest that it could result in fat mass loss [44,45]. Moreover, tai chi may help in maintaining bone mineral density and improving body composition [21]. Similarly, a 6 month study with yoga exercise intervention showed a significant improvement in balance (timed one-legged stand and forward flexibility) in the elderly population (65-85 years) [46]. In addition, an 8 week Pilates exercise program on postmenopausal women ( $>60$ years old) revealed a significant decrease in percent body 
fat and increase in lean body mass [47]. The effect of tai chi, yoga, and Pilates on OSO population has not been widely studied. Regardless, there is enough evidence to suggest that these activities have the potential to be used for treatment or prevention of OSO [21,48]. Nevertheless, more research is needed in this area.

On a different note, in the past few years, research has looked into the effects of whole body vibration on bone mineral density and body composition. Whole body vibration seems to be an alternative treatment option for older population who are not able to perform conventional exercise due to chronic conditions, such as chronic obstructive pulmonary disease [49], chronic heart failure [50], etc. Three whole body vibration sessions per week for 12 weeks may increase leg power and bone formation in older individuals [51]. Moreover, the results of several meta-analyses suggest that whole body vibration may improve bone mineral density in postmenopausal women and reduce the risk of fall and fracture $[52,53]$. Therefore, whole body vibration seems to be a promising intervention for treatment of OSO syndrome.

Prescribing exercise (even in the form of low intensity or habitual activity) is needed to maintain or improve bone mineral density [21,54-57], maintain muscle strength and muscle quality, reduce adiposity, and improve balance $[21,48,58]$. A significant negative correlation has been reported between total hours of unconventional physical activity/week and waist circumference in postmenopausal women. In addition, total hours of habitual physical activity (gardening, housework, etc.) and the average number of steps climbed were negatively correlated with total body fat percentage, body mass index (BMI), and hip and abdominal circumference [25]. Thus, even low-intensity exercise or habitual activities may maintain the bone mineral density and muscle mass, and reduce the risk of obesity for OSO syndrome. A recent recommendation for OSO population has emphasized the importance of comprehensive exercise program matched with the balance and strength of each individual $[18,21]$. The goal is to improve functionality, quality of life, and most importantly, prevent falls.

\section{Physical and Functional Performance Tests to Evaluate OSO Syndrome}

Decreased physical function by aging can indicate an increased risk for morbidity and long-term disability $[38,59]$. Specific measurements are required to evaluate balance, strength, and endurance in the older population. Handgrip strength, knee isometric strength, sit-to-stand test (to measure lower body strength, balance, and range of motion), $4 \mathrm{~m}$ timed normal and brisk walk tests (to measure locomotion), 2 min walk test (to measure endurance), and timed one leg stance (to measure balance) are all parts of the recommended measurements for OSO syndrome [2,60-62]. These tests are valuable measurements to assess fall risk and evaluate changes or deficits in body composition preceding OSO syndrome.

Handgrip strength has been used as a powerful predictor of functional abilities in older adults [63,64]. Several studies reported that loss of handgrip strength is associated with lower bone mineral density $[65,66]$. Moreover, poorer handgrip strength is associated with increased risk of falls $[63,64]$. Women identified with OSO syndrome have a poorer handgrip score in comparison to only obese population [27]. Furthermore, lower handgrip strength is reported to be associated with malnutrition, which exacerbates the loss of bone and lean mass $[67,68]$.

Some researchers view muscle quality as a more reliable measurement of functional status than strength alone [69]. Muscle quality can be measured as maximal force production per unit of muscle mass [69]. A one-repetition max from the knee extension divided by leg lean mass $(\mathrm{kg})$ has been used as a measurement of muscle quality [70]. Results of a recent study revealed that older adults with OSO syndrome had significantly lower knee extension scores than the individuals identified by only obese or osteopenic obese, which may further reinforce the association between the combined impact of bone loss, sarcopenia, and obesity, with the overall loss of fitness [24]. Although aging, myosteatosis, and chronic diseases affect the muscle quality, strength training can improve the condition $[4,69,71]$.

Also, the sit-to-stand test has been used to measure balance and range of motion in the lower extremities [72-74]. Based on Center for Disease Control and Prevention (CDC) recommendations 
a cut-off point of ten sit-to-stands in $30 \mathrm{~s}$ was used to determine the risk of fall [75]. Women ages 75-79 years who performed less than ten sit-to-stands were classified as "below average strength" for lower body evaluation. Poorer sit-to-stand test scores have been associated with slower walking pace [66,76]. Drey et al. [77] found a statistically significant decline in sit-to-stand score in osteosarcopenic population in comparison to only osteopenic or only obese individuals. The sit-to-stand test has also been used to evaluate OSO population; lower sit-to-stand scores in older adults with OSO were reported in comparison to osteopenic obese, only osteopenic, and only sarcopenic [24].

Walking speed is another predictor of functional status and frailty in older populations [78-80]. Higher fat accumulation in the lower extremities is correlated with slower walking speeds [66]. In addition, higher femoral neck bone mineral density is associated with faster walking speed [65]. In a study conducted on postmenopausal women (age of $61.6 \pm 7.4$ years), the OSO population presented the slowest normal and brisk walking speed in comparison to sarcopenic obese and osteopenic obese population [38].

In addition, the one-leg stance is a reliable assessment of balance in older adults $[65,66]$. The scores for this test decrease with age [2,81]. Balance impairment is associated with reduced gait speed [82]. A study conducted by Shin et al., [66] revealed a $21 \%$ decrease in ability to stand with each leg (30 s) as total body and gynoid region fat increase by $1 \%$ in the older population.

Overall, the physical and functional test results of several studies reinforce the concept that older women with OSO syndrome are more prone to greater functional decline than those who have each aspect of this syndrome separately. A significant weakening in the OSO population in regard to sit-to-stand and knee extension scores and slower walking speed indicate a greater loss of strength in the quadriceps muscles.

\section{Fall Prevention in OSO Syndrome}

The increased risk of falls and hip fractures is probably of the greatest concern for the OSO population [38,48]. Fall-related injuries are one of the major causes of mortality and disability among the older individuals [83]. The intensity of exercise should never surpass the physical ability of older adults and it should not increase the risk of fall, as according to CDC, falls are leading cause of injury and death in older American adults [84], and the second leading cause of accidental or unintentional injury deaths globally [85]. In addition, each year, an estimated 646,000 individuals die from falls worldwide [85]. One out of every five falls causes serious injury, such as head injury or bone fracture [84]. Moreover, one out of three fall-related deaths were attributable to low bone mineral density [83]. Bone fractures, especially in the elderly, can lead to long-term disability, institutionalization, and even mortality [86,87].

A number of risk factors related to falls have been identified. Being female, independent living, previous history of falls, physical disability, use of a walking aid, fear of falling, Parkinson's disease, vertigo, and visual/sensory deficits were associated with higher risk of fall in community-dwelling older adults [88]. Moreover, a study on Mexican older adults ( $>60$ years old) has shown obesity, depressive symptoms, and urinary incontinence were significant factors associated with falls [89]. Fall risk factors can be classified as extrinsic factors which reflect medication and home hazards, or intrinsic factors which include overall functional status [48]. The previous history of falls, muscle strength, postural instability, and fear of falling are independent predictors of fall in the older population [90-92]. It has also been reported that obesity, concurrent with low muscle strength, is associated with higher fall risk score among older adults [93]. Furthermore, persistent vitamin D deficiency in the elderly is associated with increased risk of falls and fractures [94]. The association of osteoporosis and sarcopenia with fall risk factors has been reported previously [95].

As OSO syndrome is a fundamental health challenge, a multifactorial approach should be considered to reduce the risk of fall and fracture. OSO individuals may benefit from comprehensive physical activity program, nutritional intervention, and pharmacological treatment for preventing 
fall $[18,48]$. Since extensive diet-induced weight loss in older obese adults can lead to further impaired physical function by accelerating bone loss [96] and fat-free mass loss [97], a proper nutritional intake is principal in preventing fall and fracture. It is of paramount importance for the management of osteoporosis and the prevention of falls to achieve an adequate intake of calcium and vitamin D and also engage with healthy lifestyle habits. Active lifestyle and avoidance of tobacco, alcohol, and drug consumption, such as long-term use of corticosteroids (unless there is an indication) all have an important role in reducing the risk of fall and fracture $[18,48,89]$. It has also been described that vitamin D supplement may improve muscle strength, and reduce the risk of falls and mortality in postmenopausal women $[98,99]$. Moreover, active vitamin D treatment may prevent and treat both osteoporosis and sarcopenia [100].

Although physical activity alone has been described to have beneficial effects on reducing the risk of fall [101], combining exercise with other strategies, including education, has been shown to be even more effective [102]. The long-term balance training program and tai chi, as an alternative, have shown to be effective in improving functional balance and reducing the risk of fall in elderly women $[103,104]$. Furthermore, it has been described that whole body vibration intervention reduces fall risk factors [105].

Also, a dramatic increase in the number of falls and fractures at the beginning of menopause has been linked to the decrease in estradiol serum concentrations [106]. Initiation of hormone replacement therapy soon after menopause has shown positive effects on balance, leading to a decrease in the risk of falls $[107,108]$. However, the results are still controversial [106], therefore, more clinical trials are needed to approve the use of hormone replacement therapy to improve body composition and reduce the risk of fall.

As has been previously discussed in the literature, increased body fat promotes damage to bone and muscle tissues simultaneously, weakening the bone structure and changing the muscle quality $[1,4,17,109,110]$. Compared to those who are only obese or sarcopenic, older adults with sarcopenic obesity have less physical strength and functional capacity, and are at greater risk of falls and consequently, long-term disability [111-113]. Finally, considering the complex nature of OSO syndrome, a multifactorial approach is recommended to reduce the risk of fall among elderly individuals.

\section{Discussion and Summary}

Aging causes numerous physiological changes in body composition, including a decrease in both muscle and bone mass, and a gradual increase in fat mass $[4,17,114]$. An ultimate consequence is the development of OSO syndrome [17]. One of the main risks related to changes in body composition is the higher chance of fall and fracture. Physical activity and a healthy diet may slow the progression of OSO syndrome and reduce the risk of fall. It is worth considering that low-intensity exercises, such as tai chi, yoga, Pilates, etc., or whole body vibration, can be used as alternatives for conventional exercise (aerobic and resistance training) in prevention and treatment of OSO syndrome in older adults. It is recommended that practitioners consider the individuals' chronic conditions and limitations, so that exercise could be altered according to the level of fitness and strength. Finally, OSO population should be monitored for daily levels of calcium, vitamin $\mathrm{D}$, and protein intake, to ensure maintaining an optimal diet.

Conflicts of Interest: The author declares no conflict of interest.

\section{References}

1. Ilich, J.Z.; Kelly, O.J.; Inglis, J.E.; Panton, L.B.; Duque, G.; Ormsbee, M.J. Interrelationship among muscle, fat, and bone: Connecting the dots on cellular, hormonal, and whole body levels. Ageing Res. Rev. 2014, 15, 51-60. [CrossRef] [PubMed]

2. Ilich, J.Z.; Kelly, O.J.; Inglis, J.E. Osteosarcopenic obesity syndrome: What is it and how can it be identified and diagnosed? Curr. Gerontol. Geriatr. Res. 2016, 2016, 1-7. [CrossRef] [PubMed] 
3. Stefanaki, C.; Peppa, M.; Boschiero, D.; Chrousos, G.P. Healthy overweight/obese youth: Early osteosarcopenic obesity features. Eur. J. Clin. Investig. 2016, 46, 767-778. [CrossRef] [PubMed]

4. JafariNasabian, P.; Inglis, J.E.; Reilly, W.; Kelly, O.J.; Ilich, J.Z. Aging human body: Changes in bone, muscle and body fat with consequent changes in nutrient intake. J. Endocrinol. 2017, 234, R37-R51. [CrossRef] [PubMed]

5. Cunha, P.M.; Ribeiro, A.S.; Tomeleri, C.M.; Schoenfeld, B.J.; Silva, A.M.; Souza, M.F.; Nascimento, M.A.; Sardinha, L.B.; Cyrino, E.S. The effects of resistance training volume on osteosarcopenic obesity in older women. J. Sports Sci. 2018, 36, 1564-1571. [CrossRef] [PubMed]

6. Hao, J.; Zhang, Y.; Jing, D.; Shen, Y.; Tang, G.; Huang, S.; Zhao, Z. Mechanobiology of mesenchymal stem cells: Perspective into mechanical induction of MSC fate. Acta Biomater. 2015, 20, 1-9. [CrossRef] [PubMed]

7. Ilich, J.Z.; Kelly, O.J.; Kim, Y.; Spicer, M.T. Low-grade chronic inflammation perpetuated by modern diet as a promoter of obesity and osteoporosis. Arch. Ind. Hyg. Toxicol. 2014, 65, 139-148. [CrossRef] [PubMed]

8. Deshpande, S.; James, A.W.; Blough, J.; Donneys, A.; Wang, S.C.; Cederna, P.S.; Buchman, S.R.; Levi, B. Reconciling the effects of inflammatory cytokines on mesenchymal cell osteogenic differentiation. J. Surg. Res. 2013, 185, 278-285. [CrossRef] [PubMed]

9. Gimble, J.M.; Zvonic, S.; Floyd, Z.E.; Kassem, M.; Nuttall, M.E. Playing with bone and fat. J. Cell. Biochem. 2006, 98, 251-266. [CrossRef] [PubMed]

10. Rosen, C.J.; Bouxsein, M.L. Mechanisms of disease: Is osteoporosis the obesity of bone? Nat. Clin. Pract. Rheumatol. 2006, 2, 35-43. [CrossRef] [PubMed]

11. Gilsanz, V.; Chalfant, J.; Mo, A.O.; Lee, D.C.; Dorey, F.J.; Mittelman, S.D. Reciprocal relations of subcutaneous and visceral fat to bone structure and strength. J. Clin. Endocrinol. Metab. 2009, 94, 3387-3393. [CrossRef] [PubMed]

12. Zhang, P.; Peterson, M.; Su, G.L.; Wang, S.C. Visceral adiposity is negatively associated with bone density and muscle attenuation. Am. J. Clin. Nutr. 2015, 101, 337-343. [CrossRef] [PubMed]

13. Pradhan, A.D.; Manson, J.E.; Rifai, N.; Buring, J.E.; Ridker, P.M. C-reactive protein, interleukin 6, and risk of developing type 2 diabetes mellitus. JAMA 2001, 286, 327-334. [CrossRef] [PubMed]

14. Liu, P.-Y.; Hornbuckle, L.M.; Panton, L.B.; Kim, J.-S.; Ilich, J.Z. Evidence for the association between abdominal fat and cardiovascular risk factors in overweight and obese African American women. J. Am. Coll. Nutr. 2012, 31, 126-132. [CrossRef] [PubMed]

15. Anty, R.; Bekri, S.; Luciani, N.; Saint-Paul, M.C.; Dahman, M.; Iannelli, A.; Amor, I.B.; Staccini-Myx, A.; Huet, P.M.; Gugenheim, J.; et al. The inflammatory C-reactive protein is increased in both liver and adipose tissue in severely obese patients independently from metabolic syndrome, type 2 diabetes, and NASH. Am. J. Gastroenterol. 2006, 101, 1824-1833. [CrossRef] [PubMed]

16. Saijo, Y.; Kiyota, N.; Kawasaki, Y.; Miyazaki, Y.; Kashimura, J.; Fukuda, M.; Kishi, R. Relationship between C-reactive protein and visceral adipose tissue in healthy Japanese subjects. Diabetes Obes. Metab. 2004, 6, 249-258. [CrossRef] [PubMed]

17. Ormsbee, M.J.; Prado, C.M.; Ilich, J.Z.; Purcell, S.; Siervo, M.; Folsom, A.; Panton, L. Osteosarcopenic obesity: The role of bone, muscle, and fat on health. J. Cachexia Sarcopenia Muscle 2014, 5, 183-192. [CrossRef] [PubMed]

18. JafariNasabian, P.; Inglis, J.; Kelly, O.; Ilich, J. Osteosarcopenic obesity in women: Impact, prevalence, and management challenges. Int. J. Women Health 2017, 9, 33-42. [CrossRef] [PubMed]

19. Kelly, O.J.; Gilman, J.C.; Kim, Y.; Ilich, J.Z. Micronutrient intake in the etiology, prevention and treatment of osteosarcopenic obesity. Curr. Aging Sci. 2016, 9, 260-278. [CrossRef] [PubMed]

20. Kelly, O.J.; Gilman, J.C.; Kim, Y.; Ilich, J.Z. Macronutrient intake and distribution in the etiology, prevention and treatment of osteosarcopenic obesity. Curr. Aging Sci. 2017, 10, 83-105. [CrossRef] [PubMed]

21. Kelly, O.J.; Gilman, J.C. Can unconventional exercise be helpful in the treatment, management and prevention of osteosarcopenic obesity? Curr. Aging Sci. 2016, 10, 106-121. [CrossRef] [PubMed]

22. Kanis, J.A.; Melton, L.J.; Christiansen, C.; Johnston, C.C.; Khaltaev, N. The diagnosis of osteoporosis. J. Bone Miner. Res. 1994, 9, 1137-1141. [CrossRef] [PubMed]

23. Obesity Algorithm: Clinical Guidelines for Obesity Treatment the American Society of Bariatric Physicians (ASBP), Obes. Algorithm. 2015. Available online: http:/ / obesitymedicine.org/obesity-algorithm/ (accessed on 26 January 2017). 
24. Inglis, J.E. Identifying Osteosarcopenic Obesity in a Group of Older Women. Ph.D. Thesis, The Florida State University, Tallahassee, FL, USA, 2017.

25. JafariNasabian, P. Analyzing Bone, Muscle and Adipose Tissue Biomarkers to Identify Osteosarcopenic Obesity Syndrome in Older Women. Ph.D. Thesis, The Florida State University, Tallahassee, FL, USA, 2017.

26. Inglis, J.E.; Jafarinasabian, P.; Hebrock, H.; Ave, M.; Goosby, K.; Beyer, E.; Artese, A.; Panton, L.; Ilich-Ernst, J. Older women with osteosarcopenic obesity have lower handgrip strength and knee extension strength than osteopenic or obese-only women. Adv. Nutr. 2017, 8, 9.

27. JafariNasabian, P.; Inglis, J.E.; Ave, M.P.; Hall, K.J.; Nieto, S.E.; Kelly, O.J.; Ilich, J.Z. Metabolic profile of osteosarcopenic obesity syndrome: Identifying biomarkers for diagnostic criteria. FASEB J. 2017, 31, 151-155.

28. Inglis, J.E.; JafariNasabian, P.; Gilman, J.C.; Kelly, O.J.; Ilich, J.Z. Possible nutritional etiology of osteosarcopenic obesity syndrome. FASEB J. 2016, 30, 1156-1158.

29. Pray, L.; Boon, C.; Ann Miller, E.; Pillsbury, L. Providing Healthy and Safe Foods as We Age: Workshop Summary; National Academies Press: Washington, DC, USA, 2010.

30. Kim, J.; Lee, Y.; Kye, S.; Chung, Y.-S.; Lee, O. Association of serum vitamin D with osteosarcopenic obesity: Korea National Health and Nutrition Examination Survey 2008-2010. J. Cachexia Sarcopenia Muscle 2016, 8, 259-266. [CrossRef] [PubMed]

31. Bales, C.W.; Ritchie, C.S. Sarcopenia, weight loss, and nutritional frailty in the elderly. Annu. Rev. Nutr. 2002, 22, 309-323. [CrossRef] [PubMed]

32. Morley, J.E. Anorexia, sarcopenia, and aging. Nutrition 2001, 17, 660-663. [CrossRef]

33. Heaney, R.P.; Layman, D.K. Amount and type of protein influences bone health. Am. J. Clin. Nutr. 2008, 87, 1567S-1570S. [CrossRef] [PubMed]

34. Cuenca-Sánchez, M.; Navas-Carrillo, D.; Orenes-Piñero, E. Controversies surrounding high-protein diet intake: Satiating effect and kidney and bone health. Adv. Nutr. 2015, 6, 260-266. [CrossRef] [PubMed]

35. Volpi, E.; Campbell, W.W.; Dwyer, J.T.; Johnson, M.A.; Jensen, G.L.; Morley, J.E.; Wolfe, R.R. Is the optimal level of protein intake for older adults greater than the recommended dietary allowance? J. Gerontol. A Biol. Sci. Med. Sci. 2013, 68, 677-681. [CrossRef] [PubMed]

36. Szychlinska, M.A.; Castrogiovanni, P.; Trovato, F.M.; Nsir, H.; Zarrouk, M.; Furno, D.L.; Di Rosa, M.; Imbesi, R.; Musumeci, G. Physical activity and Mediterranean diet based on olive tree phenolic compounds from two different geographical areas have protective effects on early osteoarthritis, muscle atrophy and hepatic steatosis. Eur. J. Nutr. 2018. [CrossRef] [PubMed]

37. Trovato, F.M.; Castrogiovanni, P.; Szychlinska, M.A.; Purrello, F.; Musumeci, G. Impact of Western and Mediterranean Diets and Vitamin D on Muscle Fibers of Sedentary Rats. Nutrients 2018, 10, 231. [CrossRef] [PubMed]

38. Ilich, J.Z.; Inglis, J.E.; Kelly, O.J.; McGee, D.L. Osteosarcopenic obesity is associated with reduced handgrip strength, walking abilities, and balance in postmenopausal women. Osteoporos. Int. 2015, 26, 2587-2595. [CrossRef] [PubMed]

39. Donnelly, J.E.; Smith, B.K. Is exercise effective for weight loss with ad libitum diet? Energy balance, compensation, and gender differences. Exerc. Sport Sci. Rev. 2005, 33, 169-174. [CrossRef] [PubMed]

40. Marques, E.A.; Mota, J.; Carvalho, J. Exercise effects on bone mineral density in older adults: A meta-analysis of randomized controlled trials. Age 2012, 34, 1493-1515. [CrossRef] [PubMed]

41. Turner, C.H.; Robling, A.G. Exercise as an anabolic stimulus for bone. Curr. Pharm. Des. 2004, 10, $2629-2641$. [CrossRef] [PubMed]

42. Aragão, F.R.; Abrantes, C.G.; Gabriel, R.E.; Sousa, M.F.; Castelo-Branco, C.; Moreira, M.H. Effects of a 12-month multi-component exercise program on the body composition of postmenopausal women. Climacteric 2014, 17, 155-163. [CrossRef] [PubMed]

43. Bethancourt, H.J.; Rosenberg, D.E.; Beatty, T.; Arterburn, D.E. Barriers to and facilitators of physical activity program use among older adults. Clin. Med. Res. 2014, 12, 10-20. [CrossRef] [PubMed]

44. Dechamps, A.; Gatta, B.; Bourdel-Marchasson, I.; Tabarin, A.; Roger, P. Pilot study of a 10-week multidisciplinary Tai Chi intervention in sedentary obese women. Clin. J. Sport Med. 2009, 19, 49-53. [CrossRef] [PubMed]

45. Yu, T.-Y.; Pei, Y.-C.; Lau, Y.-C.; Chen, C.-K.; Hsu, H.-C.; Wong, A.M.K. Comparison of the effects of swimming and Tai Chi Chuan on body fat composition in elderly people. Chang Gung Med. J. 2007, 30, 128-134. [PubMed] 
46. Oken, B.S.; Zajdel, D.; Kishiyama, S.; Flegal, K.; Dehen, C.; Haas, M.; Kraemer, D.F.; Lawrence, J.; Leyva, J. Randomized, controlled, six-month trial of yoga in healthy seniors: Effects on cognition and quality of life. Altern. Ther. Health Med. 2006, 12, 40-47. [PubMed]

47. Fourie, M.; Gildenhuys, G.; Shaw, I.; Shaw, B.; Toriola, A.; Goon, D. Effects of a Mat Pilates Programme on Body Composition in Elderly Women. West Indian Med. J. 2013, 62. [CrossRef] [PubMed]

48. Hita-Contreras, F.; Martínez-Amat, A.; Cruz-Díaz, D.; Pérez-López, F.R. Osteosarcopenic obesity and fall prevention strategies. Maturitas 2015, 80, 126-132. [CrossRef] [PubMed]

49. Gloeckl, R.; Heinzelmann, I.; Baeuerle, S.; Damm, E.; Schwedhelm, A.L.; Diril, M.; Buhrow, D.; Jerrentrup, A.; Kenn, K. Effects of whole body vibration in patients with chronic obstructive pulmonary disease-A randomized controlled trial. Respir. Med. 2012, 106, 75-83. [CrossRef] [PubMed]

50. Lai, C.L.; Chen, H.Y.; Tseng, S.Y.; Liao, W.C.; Liu, B.T.; Lee, M.C.; Chen, H.S. Effect of whole-body vibration for 3 months on arterial stiffness in the middle-aged and elderly. Clin. Interv. Aging 2014, 9, 821-828. [CrossRef] [PubMed]

51. Corrie, H.; Brooke-Wavell, K.; Mansfield, N.J.; Cowley, A.; Morris, R.; Masud, T. Effects of vertical and side-alternating vibration training on fall risk factors and bone turnover in older people at risk of falls. Age Ageing 2015, 44, 115-122. [CrossRef] [PubMed]

52. Ma, C.; Liu, A.; Sun, M.; Zhu, H.; Wu, H. Effect of whole-body vibration on reduction of bone loss and fall prevention in postmenopausal women: A meta-analysis and systematic review. J. Orthop. Surg. Res. 2016, 11, 24. [CrossRef] [PubMed]

53. Slatkovska, L.; Alibhai, S.M.H.; Beyene, J.; Cheung, A.M. Effect of whole-body vibration on BMD: A systematic review and meta-analysis. Osteoporos. Int. 2010, 21, 1969-1980. [CrossRef] [PubMed]

54. Hughes, V.A.; Frontera, W.R.; Wood, M.; Evans, W.J.; Dallal, G.E.; Roubenoff, R.; Singh, M.A. Longitudinal muscle strength changes in older adults: Influence of muscle mass, physical activity, and health. J. Gerontol. Ser. A Biol. Sci. Med. Sci. 2001, 56, B209-B217. [CrossRef]

55. Ilich, J.Z.; Brownbill, R.A. Habitual and low-impact activities are associated with better bone outcomes and lower body fat in older women. Calcif. Tissue Int. 2008, 83, 260-271. [CrossRef] [PubMed]

56. Wolff, I.; van Croonenborg, J.J.; Kemper, H.C.; Kostense, P.J.; Twisk, J.W. The effect of exercise training programs on bone mass: A meta-analysis of published controlled trials in pre- and postmenopausal women. Osteoporos. Int. 1999, 9, 1-12. [CrossRef] [PubMed]

57. Lanyon, L.E. Functional strain as a determinant for bone remodeling. Calcif. Tissue Int. 1984, 36 (Suppl. 1), S56-S61. [CrossRef] [PubMed]

58. Deckx, N.; Wens, I.; Nuyts, A.H.; Hens, N.; De Winter, B.Y.; Koppen, G.; Goossens, H.; Van Damme, P.; Berneman, Z.N.; Eijnde, B.O.; et al. 12 weeks of combined endurance and resistance training reduces innate markers of inflammation in a randomized controlled clinical trial in patients with multiple sclerosis. Mediat. Inflamm. 2016, 2016, 6789276. [CrossRef] [PubMed]

59. Morley, J.E.; Anker, S.D.; von Haehling, S. Prevalence, incidence, and clinical impact of sarcopenia: Facts, numbers, and epidemiology-update 2014. J. Cachexia Sarcopenia Muscle 2014, 5, 253-259. [CrossRef] [PubMed]

60. Fong, S.S.M.; Choi, A.W.M.; Luk, W.S.; Yam, T.T.T.; Leung, J.C.Y.; Chung, J.W.Y. Bone Mineral Density, Balance Performance, Balance Self-Efficacy, and Falls in Breast Cancer Survivors With and Without Qigong Training: An Observational Study. Integr. Cancer Ther. 2018, 17, 124-130. [CrossRef] [PubMed]

61. Reuben, D.B.; Magasi, S.; McCreath, H.E.; Bohannon, R.W.; Wang, Y.C.; Bubela, D.J.; Rymer, W.Z.; Beaumont, J.; Rine, R.M.; Lai, J.S.; et al. Motor assessment using the NIH Toolbox. Neurology 2013, 80 (Suppl. 3), S65-S75. [CrossRef] [PubMed]

62. Kuh, D.; Karunananthan, S.; Bergman, H.; Cooper, R. A life-course approach to healthy ageing: Maintaining physical capability. Proc. Nutr. Soc. 2014, 73, 237-248. [CrossRef] [PubMed]

63. Cruz-Jentoft, A.J.; Baeyens, J.P.; Bauer, J.M.; Boirie, Y.; Cederholm, T.; Landi, F.; Martin, F.C.; Michel, J.P.; Rolland, Y.; Schneider, S.M.; et al. Sarcopenia: European consensus on definition and diagnosis: Report of the European Working Group on Sarcopenia in Older People. Age Ageing 2010, 39, 412-423. [CrossRef] [PubMed]

64. Savino, E.; Martini, E.; Lauretani, F.; Pioli, G.; Zagatti, A.M.; Frondini, C.; Pellicciotti, F.; Giordano, A.; Ferrari, A.; Nardelli, A.; et al. Handgrip strength predicts persistent walking recovery after hip fracture surgery. Am. J. Med. 2013, 126, 1068-1075. [CrossRef] [PubMed] 
65. Lindsey, C.; Brownbill, R.A.; Bohannon, R.A.; Ilich, J.Z. Association of Physical Performance Measures with Bone Mineral Density in Postmenopausal Women. Arch. Phys. Med. Rehabil. 2005, 86, 1102-1107. [CrossRef] [PubMed]

66. Shin, H.; Liu, P.-Y.; Panton, L.B.; Ilich, J.Z. Physical performance in relation to body composition and bone mineral density in healthy, overweight, and obese postmenopausal women. J. Geriatr. Phys. Ther. 2014, 37, 7-16. [CrossRef] [PubMed]

67. Wang, L.; Song, Y.; Manson, J.E.; Pilz, S.; März, W.; Michaëlsson, K.; Lundqvist, A.; Jassal, S.K.; Barrett-Connor, E.; Zhang, C.; et al. Circulating 25-hydroxy-vitamin D and risk of cardiovascular disease: A meta-analysis of prospective studies. Circ. Cardiovasc. Qual. Outcomes 2012, 5, 819-829. [CrossRef] [PubMed]

68. Bin, C.M.; Flores, C.; Álvares-da-Silva, M.R.; Francesconi, C.F.M. Comparison between Handgrip Strength, Subjective Global Assessment, Anthropometry, and Biochemical Markers in Assessing Nutritional Status of Patients with Crohn's Disease in Clinical Remission. Dig. Dis. Sci. 2010, 55, 137-144. [CrossRef] [PubMed]

69. Brooks, N.; Layne, J.E.; Gordon, P.L.; Roubenoff, R.; Nelson, M.E.; Castaneda-Sceppa, C. Strength training improves muscle quality and insulin sensitivity in Hispanic older adults with type 2 diabetes. Int. J. Med. Sci. 2006, 4, 19-27. [CrossRef] [PubMed]

70. Wood, R.J.; Gregory, S.; Maneen, J.; Sullivan, R.; Richard, J.; Sawyer, J.; Matthews, T.D.; Headley, S.A. Weight loss and muscle quality in older men with metabolic syndrome. FASEB J. 2011, 25, 982.

71. Taaffe, D.R.; Henwood, T.R.; Nalls, M.A.; Walker, D.G.; Lang, T.F.; Harris, T.B. Alterations in muscle attenuation following detraining and retraining in resistance-trained older adults. Gerontology 2009, 55, 217-223. [CrossRef] [PubMed]

72. Nevitt, M.C.; Cummings, S.R.; Kidd, S.; Black, D. Risk factors for recurrent nonsyncopal falls. A prospective study. JAMA 1989, 261, 2663-2668. [CrossRef] [PubMed]

73. Lord, S.R.; Murray, S.M.; Chapman, K.; Munro, B.; Tiedemann, A. Sit-to-Stand Performance Depends on Sensation, Speed, Balance, and Psychological Status in Addition to Strength in Older People. J. Gerontol. Ser. A Biol. Sci. Med. Sci. 2002, 57, M539-M543. [CrossRef]

74. Lindemann, U.; Claus, H.; Stuber, M.; Augat, P.; Muche, R.; Nikolaus, T.; Becker, C. Measuring power during the sit-to-stand transfer. Eur. J. Appl. Physiol. 2003, 89, 466-470. [CrossRef] [PubMed]

75. Centers for Disease Control and Pervention. 30-Second Chair Stand. 2017. Available online: https://www. cdc.gov/steadi/pdf/STEADI-Assessment-30Sec-508.pdf (accessed on 25 April 2018).

76. Bernabeu-Mora, R.; Medina-Mirapeix, F.; Llamazares-Herrán, E.; Oliveira-Sousa SL de Sánchez-Martinez, M.P.; Escolar-Reina, $P$. The accuracy with which the 5 times sit-to-stand test, versus gait speed, can identify poor exercise tolerance in patients with COPD: A cross-sectional study. Medicine 2016, 95, e4740. [CrossRef] [PubMed]

77. Drey, M.; Sieber, C.C.; Bertsch, T.; Bauer, J.M.; Schmidmaier, R.; FiAT Intervention Group. Osteosarcopenia is more than sarcopenia and osteopenia alone. Aging Clin. Exp. Res. 2016, 28, 895-899. [CrossRef] [PubMed]

78. Theou, O.; Jones, G.R.; Jakobi, J.M.; Mitnitski, A.; Vandervoort, A.A. A comparison of the relationship of 14 performance-based measures with frailty in older women. Appl. Physiol. Nutr. Metab. 2011, 36, 928-938. [CrossRef] [PubMed]

79. Lusardi, M.M. Is Walking Speed a Vital Sign? Absolutely! Top. Geriatr. Rehabil. 2012, 28, 67-76. [CrossRef]

80. Middleton, A.; Fritz, S.L.; Lusardi, M. Walking speed: The functional vital sign. J. Aging Phys. Act. 2015, 23, 314-322. [CrossRef] [PubMed]

81. Najafi, D.A.; Dahlberg, L.E.; Hansson, E.E. A combination of clinical balance measures and FRAX ${ }^{\circledR}$ to improve identification of high-risk fallers. BMC Geriatr. 2016, 16, 94. [CrossRef] [PubMed]

82. Peirone, E.; Goria, P.F.; Anselmino, A. A dual-task home-based rehabilitation programme for improving balance control in patients with acquired brain injury: A single-blind, randomized controlled pilot study. Clin. Rehabil. 2014, 28, 329-338. [CrossRef] [PubMed]

83. Sànchez-Riera, L.; Carnahan, E.; Vos, T.; Veerman, L.; Norman, R.; Lim, S.S.; Hoy, D.; Smith, E.; Wilson, N.; Nolla, J.M.; et al. The global burden attributable to low bone mineral density. Ann. Rheum. Dis. 2014, 73, 1635-1645. [CrossRef] [PubMed]

84. Falls are Leading Cause of Injury and Death in Older Americans. CDC Online Newsroom. 2016. Available online: https: / / www.cdc.gov/media/releases/2016/p0922-older-adult-falls.html (accessed on 24 April 2018).

85. Falls World Heal. Organ. 2018. Available online: http://www.who.int/en/news-room/fact-sheets/detail/ falls (accessed on 24 April 2018). 
86. Kanis, J.A.; Johnell, O.; Oden, A.; Jonsson, B.; De Laet, C.; Dawson, A. Risk of hip fracture according to the World Health Organization criteria for osteopenia and osteoporosis. Bone 2000, 27, 585-590. [CrossRef]

87. Eastell, R.; Wahner, H.W.; O'Fallon, W.M.; Amadio, P.C.; Melton, L.J.; Riggs, B.L. Unequal decrease in bone density of lumbar spine and ultradistal radius in Colles' and vertebral fracture syndromes. J. Clin. Investig. 1989, 83, 168-174. [CrossRef] [PubMed]

88. Deandrea, S.; Lucenteforte, E.; Bravi, F.; Foschi, R.; La Vecchia, C.; Negri, E. Risk Factors for Falls in Community-dwelling Older People: A Systematic Review and Meta-analysis. Epidemiology 2010, 21, 658-668. [CrossRef] [PubMed]

89. Valderrama-Hinds, L.M.; Al Snih, S.; Chen, N.; Rodriguez, M.A.; Wong, R. Falls in Mexican older adults aged 60 years and older. Aging Clin. Exp. Res. 2018. [CrossRef] [PubMed]

90. Murphy, S.L.; Williams, C.S.; Gill, T.M. Characteristics associated with fear of falling and activity restriction in community-living older persons. J. Am. Geriatr. Soc. 2002, 50, 516-520. [CrossRef] [PubMed]

91. Hita-Contreras, F.; Martínez-Amat, A.; Lomas-Vega, R.; Álvarez, P.; Aránega, A.; Martínez-López, E.; Mendoza, N. Predictive value of stabilometry and fear of falling on falls in postmenopausal women. Climacteric 2013, 16, 584-589. [CrossRef] [PubMed]

92. Scheffer, A.C.; Schuurmans, M.J.; van Dijk, N.; van der Hooft, T.; de Rooij, S.E. Fear of falling: Measurement strategy, prevalence, risk factors and consequences among older persons. Age Ageing 2008, 37, 19-24. [CrossRef] [PubMed]

93. Scott, D.; Sanders, K.M.; Aitken, D.; Hayes, A.; Ebeling, P.R.; Jones, G. Sarcopenic obesity and dynapenic obesity: 5-year associations with falls risk in middle-aged and older adults. Obesity 2014, 22, 1568-1574. [CrossRef] [PubMed]

94. Kaji, H. Linkage between muscle and bone: Common catabolic signals resulting in osteoporosis and sarcopenia. Curr. Opin. Clin. Nutr. Metab. Care 2013, 16, 272-277. [CrossRef] [PubMed]

95. Hita-Contreras, F.; Martínez-López, E.; González-Matarín, P.; Mendoza, N.; Cruz-Díaz, D.; Ruiz-Ariza, A.; Martínez-Amat, A. Association of bone mineral density with postural stability and the fear of falling in Spanish postmenopausal women. Maturitas 2014, 79, 322-328. [CrossRef] [PubMed]

96. Beavers, D.P.; Beavers, K.M.; Loeser, R.F.; Walton, N.R.; Lyles, M.F.; Nicklas, B.J.; Shapses, S.A.; Newman, J.J.; Messier, S.P. The independent and combined effects of intensive weight loss and exercise training on bone mineral density in overweight and obese older adults with osteoarthritis. Osteoarthr. Cartil. 2014, 22, 726-733. [CrossRef] [PubMed]

97. Villareal, D.T.; Apovian, C.M.; Kushner, R.F.; Klein, S. American Society for Nutrition, NAASO, The Obesity Society. Obesity in Older Adults: Technical Review and Position Statement of the American Society for Nutrition and NAASO. Obes. Res. 2005, 13, 1849-1863. [CrossRef] [PubMed]

98. Morley, J.E.; Argiles, J.M.; Evans, W.J.; Bhasin, S.; Cella, D.; Deutz, N.E.; Doehner, W.; Fearon, K.C.; Ferrucci, L.; Hellerstein, M.K.; et al. Nutritional recommendations for the management of sarcopenia. J. Am. Med. Dir. Assoc. 2010, 11, 391-396. [CrossRef] [PubMed]

99. Pérez-López, F.R.; Brincat, M.; Erel, C.T.; Tremollieres, F.; Gambacciani, M.; Lambrinoudaki, I.; Moen, M.H.; Schenck-Gustafsson, K.; Vujovic, S.; Rozenberg, S.; et al. EMAS position statement: Vitamin D and postmenopausal health. Maturitas 2012, 71, 83-88. [CrossRef] [PubMed]

100. Tanaka, K.; Kanazawa, I.; Yamaguchi, T.; Yano, S.; Kaji, H.; Sugimoto, T. Active vitamin D possesses beneficial effects on the interaction between muscle and bone. Biochem. Biophys. Res. Commun. 2014, 450, 482-487. [CrossRef] [PubMed]

101. Petridou, E.T.; Manti, E.G.; Ntinapogias, A.G.; Negri, E.; Szczerbińska, K. What Works Better for Community-Dwelling Older People at Risk to Fall? J. Aging Health 2009, 21, 713-729. [CrossRef] [PubMed]

102. Jung, D.; Lee, J.; Lee, S.-M. A Meta-Analysis of Fear of Falling Treatment Programs for the Elderly. West. J. Nurs. Res. 2009, 31, 6-16. [CrossRef] [PubMed]

103. Madureira, M.M.; Bonfá, E.; Takayama, L.; Pereira, R.M.R. A 12-month randomized controlled trial of balance training in elderly women with osteoporosis: Improvement of quality of life. Maturitas 2010, 66, 206-211. [CrossRef] [PubMed]

104. Schleicher, M.M.; Wedam, L.; Wu, G. Review of Tai Chi as an effective exercise on falls prevention in elderly. Res. Sports Med. 2012, 20, 37-58. [CrossRef] [PubMed] 
105. Álvarez-Barbosa, F.; del Pozo-Cruz, J.; del Pozo-Cruz, B.; Alfonso-Rosa, R.M.; Rogers, M.E.; Zhang, Y. Effects of supervised whole body vibration exercise on fall risk factors, functional dependence and health-related quality of life in nursing home residents aged 80+. Maturitas 2014, 79, 456-463. [CrossRef] [PubMed]

106. Ribom, E.L.; Piehl-Aulin, K.; Ljunghall, S.; Ljunggren, O.; Naessén, T. Six months of hormone replacement therapy does not influence muscle strength in postmenopausal women. Maturitas 2002, 42, 225-231. [CrossRef]

107. Barral, A.B.; Nahas, E.A.; Nahas-Neto, J.; Cangussu, L.M.; de Araujo Buttros, D. Effect of hormone therapy on postural balance in postmenopausal women. Menopause 2012, 19, 768-775. [CrossRef] [PubMed]

108. Randell, K.M.; Honkanen, R.J.; Komulainen, M.H.; Tuppurainen, M.T.; Kröger, H.; Saarikoski, S. Hormone replacement therapy and risk of falling in early postmenopausal women-A population-based study. Clin. Endocrinol. 2001, 54, 769-774. [CrossRef]

109. Kawai, M.; de Paula, F.J.A.; Rosen, C.J. New insights into osteoporosis: The bone-fat connection. J. Intern. Med. 2012, 272, 317-329. [CrossRef] [PubMed]

110. Hamrick, M.W.; McGee-Lawrence, M.E.; Frechette, D.M. Fatty infiltration of skeletal muscle: Mechanisms and comparisons with bone marrow adiposity. Front. Endocrinol. 2016, 7, 69. [CrossRef] [PubMed]

111. Domiciano, D.S.; Figueiredo, C.P.; Lopes, J.B.; Caparbo, V.F.; Takayama, L.; Menezes, P.R.; Bonfa, E.; Pereira, R.M. Discriminating sarcopenia in community-dwelling older women with high frequency of overweight/obesity. Osteoporos. Int. 2013, 24, 595-603. [CrossRef] [PubMed]

112. Baumgartner, R.N. Body composition in healthy aging. Ann. N. Y. Acad. Sci. 2000, 904, 437-448. [CrossRef] [PubMed]

113. Mijnarends, D.M.; Schols, J.M.; Meijers, J.M.; Tan, F.E.; Verlaan, S.; Luiking, Y.C.; Morley, J.E.; Halfens, R.J. Instruments to Assess Sarcopenia and Physical Frailty in Older People Living in a Community (Care) Setting: Similarities and Discrepancies. J. Am. Med. Dir. Assoc. 2015, 16, 301-308. [CrossRef] [PubMed]

114. Liu, P.-Y.; Ilich, J.Z.; Brummel-Smith, K.; Ghosh, S. New insight into fat, muscle and bone relationship in women: Determining the threshold at which body fat assumes negative relationship with bone mineral density. Int. J. Prev. Med. 2014, 5, 1452-1463. [PubMed]

(C) 2018 by the author. Licensee MDPI, Basel, Switzerland. This article is an open access article distributed under the terms and conditions of the Creative Commons Attribution (CC BY) license (http://creativecommons.org/licenses/by/4.0/). 